\title{
A description of body growth and composition of South African Black ostriches (Struthio camelus var. domesticus) under free-choice feeding conditions
}

\author{
T.S. Brand ${ }^{1,2 \#, ~ W . J . ~ K r i t z i n g e r ~}{ }^{2}$, L.C. Hoffman ${ }^{2}$ \& R.M. Gous ${ }^{3}$ \\ ${ }^{1}$ Institute for Animal Production, Western Cape Department of Agriculture, Private Bag X1, Elsenburg 7607, \\ South Africa; ${ }^{2}$ Department of Animal Sciences, University of Stellenbosch, Private Bag X1, Stellenbosch, 7602, \\ South Africa; ${ }^{3}$ Animal and Poultry Science, University of KwaZulu-Natal, Pietermaritzburg, 3200, South Africa \\ Copyright resides with the authors in terms of the Creative Commons Attribution 2.5 South African Licence. \\ See: http://creativecommons.org/licenses/by/2.5/za/ \\ Condition of use: The user may copy, distribute, transmit and adapt the work, but must recognise the authors and the South African Journal \\ of Animal Science
}

\begin{abstract}
This study describes changes occurring in the live weight and body composition of male and female South African Black ostriches over a growing period of 285 days. Forty-five birds were given four diets with different protein (ca. 180 and ca. $120 \mathrm{~g} / \mathrm{kg}$ feed) and energy (ca. 8.5 and ca. $13.5 \mathrm{MJ} \mathrm{ME} / \mathrm{kg}$ feed) levels on a free choice basis, assuming that the birds would select feeds according to their protein and energy requirements and subsequently growing close to their genetic potential. Birds were weighed at approximately 10-day intervals and randomly selected birds $(n=9)$ were slaughtered at 1, 54, 120, 162 and 285 days of age respectively. Proximate chemical analyses were done on the complete empty carcasses and the components were expressed as a percentage of live weight at the different slaughter ages. An adapted form of the Gompertz growth curve $\left(\mathrm{W}_{\mathrm{t}}=\mathrm{W}_{\mathrm{m}} *\left(\exp \left(-\exp \left(-\mathrm{B}^{*}\left(\mathrm{t}-\mathrm{t}^{*}\right)\right)\right)\right.\right.$ ) (where $\mathrm{W}_{\mathrm{t}}$ is body weight $(\mathrm{kg})$ at time $\mathrm{t}(\mathrm{d}), \mathrm{W}_{\mathrm{m}}$ is the mature weight $(\mathrm{kg})$, B the rate of maturing (/d) and $\mathrm{t}^{*}$ the age (d) at which growth rate is maximised), was fitted to the live weight data and the weights of each chemical component (calculated from percentage of total body weight). The growth parameters $\mathrm{W}_{\mathrm{m}}, \mathrm{B}$ and $\mathrm{t}^{*}$ were calculated for each chemical component. The growth parameters $\mathrm{W}_{\mathrm{m}}, \mathrm{B}$ and $\mathrm{t}^{*}$ were estimated as $119 \mathrm{~kg}, 0.009 / \mathrm{d}$ and $156 \mathrm{~d}$ respectively. Gompertz parameters estimated for the different chemical components were: $B W a_{m}=55.0, B=0.014$ and $t^{*}=117$ for moisture, $\mathrm{BP}_{\mathrm{m}}=44.5, \mathrm{~B}=0.015$ and $\mathrm{t}^{*}=114$ for protein, $\mathrm{BLip}_{\mathrm{m}}=33.6, \mathrm{~B}=0.013$ and $\mathrm{t}^{*}=143$ for lipid, and Bash $_{\mathrm{m}}=10.3, \mathrm{~B}=0.016$ and $\mathrm{t}^{*}=118$ for ash. If it is assumed that ostriches in this study selected feed according to their protein and energy needs on each day of the growing period resulting in their growing close to their genetic potential, the results presented here would represent the potential growth rate of South African Black ostriches. Each chemical component was described by a Gompertz growth curve, and the rate of growth parameters illustrated that the tissues are allometrically related.
\end{abstract}

Keywords: Development, feeding optimisation, Gompertz growth curve, growth, proportional changes

\# Corresponding author: tersb@elsenburg.com

\section{Introduction}

Very little relevant research has been conducted to enable the feed intake of ostriches to be predicted, or to quantify the changes in body composition of ostriches with age using mathematical modeling (Brand \& Gous, 2006). An accurate and detailed description of animal growth is required to enable the nutrient requirements of animals to be predicted (Ferguson, 2006). Although it is not possible to predict the actual growth of any animal because of many environmental factors affecting growth, it is possible to predict the potential growth of animals, making deriving much useful information possible. The potential rate of growth of body and feather protein, for example, are used to calculate the daily amino acid requirements of a growing ostrich while the weight of body protein on any day can be used to calculate its maintenance requirement. Summing these components enables the calculation of the daily amount of each amino acid and 
energy required to support the potential growth of an ostrich. This is the first step in determining the voluntary food intake of ostriches during growth, i.e. by comparing the nutrient requirements with the dietary content of those nutrients to determine how much the bird would need to consume in order to meet its requirement for the most limiting nutrient in the feed. The question then is whether the bird can consume that 'desired' intake. If it can, then its potential growth rate will have been achieved; if not, actual growth will be lower than potential, the difference being dictated by the constrained amount of food that can be consumed (Emmans, 1989).

The aim of this study was therefore to describe the body growth and composition of South African Black ostriches using an appropriate growth curve to quantify the proportional changes and growth rates of the four main chemical constituents of the body, namely protein, water, ash and lipid.

\section{Materials and Methods}

Forty-five day-old ostrich chicks were placed in nine identical pens with five chicks per pen. Four feeds were formulated with a low (LP) and high protein (HP) (ca. 180 and ca. $120 \mathrm{~g} / \mathrm{kg}$ feed) and low (LE) and high energy (HE) (ca. 8.5 and ca. 13.5 MJ ME/kg feed) content. (See Table 1 and Table 2 for ingredient and chemical composition of the experimental diets). All four feeds were offered simultaneously and $a d$ libitum to the birds in each pen throughout the trial. Water was freely available throughout the trial.

Birds were weighed at approximately ten-day intervals throughout the trial. Randomly selected birds (1 per group) were slaughtered at 1, 54, 120, 162 and $285 \mathrm{~d}$ of age. The nine birds selected at each sampling were weighed, stunned, exsanguinated and eviscerated. Blood was collected in a separate container for each bird. The intestines of each bird were cleaned with water, and all body parts, along with the blood, feathers and clean intestines were frozen in plastic bags until the commencement of mincing. The entire body with feathers was minced and thoroughly mixed. Afterwards one randomly selected sample $( \pm 150 \mathrm{~g})$ was saved to be used for protein, moisture, ash and lipid analysis (AOAC, 2002).

An adapted form of the Gompertz growth curve $\left(\mathrm{W}_{\mathrm{t}}=\mathrm{W}_{\mathrm{m}} *\left(\exp \left(-\exp \left(-\mathrm{B}^{*}\left(\mathrm{t}-\mathrm{t}^{*}\right)\right)\right)\right)(\right.$ Emmans, 1989) (where $\mathrm{W}_{\mathrm{t}}$ is body weight $(\mathrm{kg})$ at time $\mathrm{t}(\mathrm{d}), \mathrm{W}_{\mathrm{m}}$ is the mature weight $(\mathrm{kg})$, $\mathrm{B}$ the rate of maturing $(/ \mathrm{d})$ and $\mathrm{t}^{*}$ the age (d) at which growth rate is maximised) was fitted to the live weight data and the weights of each chemical component (calculated from percentage of total body weight) using Statgraphics (2005). The growth parameters $\mathrm{W}_{\mathrm{m}}, \mathrm{B}$ and $\mathrm{t}^{*}$ were calculated for each chemical component. The accuracy of the fitted model was determined by a goodness of fit test (Mellet, 1992).

A free choice feeding system was used on the assumption that the birds would adjust their nutrient intake (Van der Merwe \& Smith, 1991; McDonald et al., 2002) minimising deficiencies and excesses of protein and energy, thereby enabling the birds to grow close to their potential without being constrained by the feed offered.

\section{Results and Discussion}

The Gompertz growth curve was fitted to the live weight data of ostriches. The equation derived from the data provides valuable information on the potential growth rate of the South African Black ostrich. The growth parameters $\mathrm{W}_{\mathrm{m}}, \mathrm{B}$ and $\mathrm{t}^{*}$ were estimated as $119 \mathrm{~kg}, 0.009 / \mathrm{d}$ and $156 \mathrm{~d}$, respectively. Gompertz parameters estimated for the different chemical components were: $\mathrm{BWa}_{\mathrm{m}}=55.0, \mathrm{~B}=0.014 \mathrm{and} \mathrm{t}^{*}=117$ for moisture, $\mathrm{BP}_{\mathrm{m}}=44.5, \mathrm{~B}=0.015$ and $\mathrm{t}^{*}=114$ for protein, $\mathrm{BLip}_{\mathrm{m}}=33.6, \mathrm{~B}=0.013$ and $\mathrm{t}^{*}=143$ for lipid, and Bash $_{\mathrm{m}}=10.3, \mathrm{~B}=0.016$ and $\mathrm{t}^{*}=118$ for ash.

The data confirm that the relative growth of the chemical components of ostriches is similar to that in other species (Lawrie, 1998; McDonald et al., 2002). The maturing rate (B) of each of the body components is similar; thus, being allometrically related. As a result the weight of each component can be predicted using a single component such as body protein weight (Ferguson, 2006; Gous \& Brand, 2008), thereby simplifying the modelling process by having to predict the growth of only one component.

If it is assumed that ostriches in this study selected feed according to their protein and energy needs on each day of the growing period and thereby grew close to their genetic potential, the results presented here would represent the potential growth rate of South African Black ostriches. Each chemical component was described by a Gompertz growth curve, and the rate of growth parameters illustrated that the tissues are allometrically related. 
Table 1 Ingredient composition of the four basal feeds used in the free choice study (HE-HP = High energyHigh protein; HE-LP = High energy-Low protein; LE-HP = Low energy-High protein; LE-LP = Low energy-Low protein)

\begin{tabular}{lcccc}
\hline Ingredients & HE-HP & HE-LP & LE-HP & LE-LP \\
\hline Maize meal & 200 & 0 & 0 & 0 \\
Barley grain & 400 & 706 & 0 & 100 \\
Oat bran & 0 & 0 & 570 & 573 \\
Wheat bran & 0 & 54 & 0 & 33 \\
Lucerne meal & 143 & 142 & 142 & 142 \\
Soybean oilcake meal & 80 & 0 & 158 & 114 \\
Full-fat Soybeans & 50 & 43 & 0 & 0 \\
Fishmeal & 75 & 0 & 88 & 0 \\
Plant oil & 10 & 20 & 0 & 0 \\
L lysine HCl & 0.46 & 0 & 0.33 & 0 \\
DL methionine & 0.96 & 4 & 1.3 & 4.3 \\
Monocalcium phosphate & 14 & 0 & 18 & 0 \\
Dicalcium phosphate & 0 & 8 & 0 & 9 \\
Limestone & 19 & 15 & 14 & 15 \\
Salt & 4 & 4 & 4 & 4 \\
Min \& Vit premix & 5 & 5 & 5 & 5 \\
\end{tabular}

Table 2 Nutrient composition (g/kg) of the four free-choice feeds used in the free choice study

\begin{tabular}{lcccc}
\hline Nutrients & HE-HP & HE-LP & LE-HP & LE-LP \\
\hline Energy, MJ ME/kg feed & 13.5 & 13.5 & 8.5 & 8.5 \\
Fat & 41 & 41 & 24 & 24 \\
Crude fibre & 77 & 108 & 204 & 214 \\
Crude protein & 216 & 155 & 218 & 161 \\
Lysine & 9 & 4 & 9 & 5 \\
Methionine & 3 & 4 & 3 & 3 \\
Cysteine & 2 & 1 & 2 & 1 \\
Arginine & 9 & 5 & 9 & 5 \\
Threonine & 6 & 6 & 10 & 6 \\
\hline
\end{tabular}

\section{Conclusion}

Knowing the potential growth rates of body protein and lipid enables the calculation of the amount of each essential amino acid, and energy, required to meet the needs for the growth of these components. Maintenance requirements can be calculated based on the weight of body protein on any day of the growing period, and together with the requirements for growth, the daily requirement for amino acids and energy can be predicted for an ostrich growing at its potential. Such information is essential when predicting the voluntary food intake of ostriches during growth. 


\section{References}

AOAC, 2002. Official methods of analysis: Revision 1 (17th ed.). Association of Official Analytical Chemists, Inc., Arlington, Virginia, USA. pp. 152-169.

Berg, R.T. \& Butterfield, R.M., 1976. New Concepts of Cattle Growth. University of Sydney Press, Sydney, Australia.

Berg, R.T., Andersen, B.B. \& Liboriussen, T., 1978. Growth of bovine tissues. Genetic influences on growth patterns of muscle, fat and bone in young bulls. Anim. Prod. 26, 245-258.

Brand, T.S. \& Gous, R.M., 2006. Feeding Ostriches. In: Feeding in Domestic Vertebrates, From Stucture to Behaviour. Ed. Bels, V., CAB International, Oxfordshire. pp. 136-155.

Brand, T.S., Nel, C.J. \& Van Schalkwyk, S.J., 2000. The effect of dietary energy and protein level on the production of growing ostriches. S. Afr. J. Anim. Sci. 30 (Suppl. 1), 15-16.

Cilliers, S.C., 1998. Feedstuff evaluation, metabolisable energy and amino acid requirements for maintenance and growth in ostriches. Prococeeding of the Second International Ratite Congress, Oudtshoorn, South Africa.

Emmans, G.C., 1989. The growth of turkeys. In: Recent Advances in Turkey Science. Eds Nixey, D. \& Grey, T.C., Poultry Science Symposium 21, Butterworths, London, UK. pp. 141-145.

Ferguson, N.S., 2006. Basic concepts describing animal growth and feed intake. In: Mechanistic Modelling in Pig \& Poultry Production. Eds Gous, R.M., Morris, T.R. \& Fisher, C., CAB International, Oxfordshire. pp. 22-54.

Gous, R.M. \& Fisher, C., 2008. Simulation models in poultry production. XXIII Wrld's Poultry Congress, Brisbane, Sydney, Australia.

Huxley, J.S., 1932. Problems of Relative Growth. Methuen and Co., Ltd., London.

Iji, P.A., Van der Walt, J.G., Brand, T.S., Boomker, E.A. \& Booyse, D., 2003. Development of the digestive tract in the ostrich (Struthio camelus). Arch. Anim. Nutr. 57, 217-228.

Lawrie, R.A., 1998. Lawrie's Meat Science, $6^{\text {th }}$ edition, Woodhead Publishing Limited. pp.11-30.

McDonald, P., Edwards, R.A., Greenhalgh, J.F.D. \& Morgan, C.A., 2002. Animal Nutrition, $6^{\text {th }}$ edition. Pearson, Prentice Hall.

Mellett, F.D., 1992. Die volstruis as slagdier: aspekte van groei. Ph.D. thesis, University of Stellenbosch, South Africa. pp. 54-55. (in Afrikaans).

Statgraphics, 2005. Statgraphics Centurion XV (Statpoint, inc.), www.statgraphics.com.

Van der Merwe, F.J. \& Smith, W.A., 1991. Dierevoeding. Anim. Sci., Pty Ltd, Pinelands, South Africa. pp. 163-168. 